\title{
Działalność „Międzyrządowej Komisji Polsko-Ukraińskiej do spraw ochrony i zwrotu dóbr kultury utraconych i bezprawnie przemieszczonych podczas II wojny światowej" w zakresie bibliotek (1996-1997) ${ }^{1}$
}

P olska i Ukraina mają bardzo wiele punktów stycznych w dziedzinie ochrony wspólnego, bądź też odrębnego, własnego dziedzictwa piśmienniczego, przechowywanego na terenie obu państw. Wiele też jest kwestii spornych wymagających racjonalnego, polubownego rozstrzygnięcia. Nic zatem dziwnego, że obie strony przywiązują znaczną wagę do prac „Międzynarodowej Komisji Polsko-Ukraińskiej do spraw ochrony i zwrotu dóbr kultury utraconych i bezprawnie przemieszczonych podczas II wojny światowej (dalej przytaczana, jako: Komisja Międzyrządowa).

Bezpośrednią podstawą prawną powołania Komisji Międzyrządowej było Porozumienie między Rzqdem Rzeczyposoplitej Polskiej a Rządem Ukrainy o wspótpracy $w$ dziedzinie ochrony $i$ zwrotu dóbr kultury utraconych i bezprawnie przemieszczonych podczas II wojny światowej zawarte 25 czerwca 1996 r. Owo zaś Porozumienie wynikało z realizacji ustaleń Traktatu między Rzeczapospolita Polska a Ukrainq o dobrym sqsiedztwie, przyjaznych stosunkach $i$ wspólpracy z dn. 18 maja 1992 r. oraz Porozumienia wstępnego między Rządem Rzeczypospolitej Polskiej a Rzqdem Ukrainy w sprawie wspólpracy kulturalnej i naukowej, podpisanego w tym samym dniu.

Porozumienie z 1996 r. stanowiło m.in.:

Art. 1. Umawiajace się Strony podejma przeprowadzenie wspólnych prac ewidencyjnych, inwentaryzacyjnych i badawczych majacych na celu ustalenie liczby, wartosici $i$ stanu zachowania znajdujacych się na terytoriach ich Państw ruchomych dóbr kultury, które sq zwiqzane z kulturq i historiq drugiej umawiajacej się Strony. Wyniki tych prac będa podawane do publicznej wiadomości przez każda z Umawiających się Stron, nie rzadziej niż raz 
wroku.

Art. 2. W celu ochrony, zachowania, poszukiwań i zwrotu dóbr kultury, zwiqzanych z kulturq i historiq Umawiajacych się Stron, a uznanych za utracone bqdź bezprawnie przemieszczone na terytorium drugiej Umawiajacej się Strony, Strony tworzq ,Międzyrzqdowa Polsko-Ukrainska Komisję" (dalej zwanq „Komisjq Międzyrzqdowq"). Komisja Międzyrzqdowa dwa razy w roku odbędzie posiedzenie kolejno w każdym z Umawiajacych się Państw.

Art. 3. Do podstawowych kierunków dzialalności Komisji Międzyrząowej należa w szczególności:

1. Poszukiwania, ewidencja oraz identyfikacja dóbr kulturalnych, będacych przedmiotem poszukiwań każdej z Umawiajacych się Stron oraz wzajemna informacja;

2. Przygotowanie wniosków badawczych dotyczacych roszczeń do dóbr kultury, przedstawionych przez obie Umawiajace się Strony.

Art. 4.

1. Komisja Międzyrzadowa może powotywać stale lub dzialajace okresowo grupy ekspertów do spraw zabytków archeologicznych, historycznych, dziel sztuki, dokumentów archiwalnych, bibliotek oraz inne (w razie konieczności).

2. Grupy ekspertów będa prowadzity poszukiwania, identyfikację i badania oraz będq opracowywaty propozycje zwrotu dóbr kultury utraconych i bezprawnie przemieszczonych na terytorium kazdej z Umawiajacych sie Stron. ${ }^{2}$

Nacisk w umowach międzynarodowych spoczywa więc na poszukiwaniu, rejestracji i zabezpieczaniu zbiorów interesujących obie strony. Ewentualne wnioski rewindykacyjne mają być uwarunkowane przeprowadzonymi uprzednio pracami badawczymi.

Realizacja Porozumienia, jakkolwiek leży ona w żywotnym interesie zarówno Polski jak Ukrainy, przebiega opornie i z narastającymi opóźnieniami.

Pierwsze spotkanie przedstawicieli obu krajów miało miejsce w Kijowie, w dn. 12-15 grudnia 1996 r. Polacy byli już przygotowani do merytorycznych obrad. Sześcioosobowej delegacji przewodniczył prof. dr hab. Tadeusz Polak, Wiceminister Kultury i Sztuki, a jednocześnie Pełnomocnik Rządu do Spraw Polskiego Dziedzictwa Kulturalnego za Granicą. W składzie delegacji znalazło się dwoje przedstawicieli bibliologii: prof. dr hab. Adam Manikowski, Dyrektor Biblioteki Narodowej i prof. dr hab. Barbara Bieńkowska, Prezes Polskiego Towarzystwa Bibliologicznego. 
Na miejscu okazało się, że gospodarze potraktowali naszę wizytę jako wstępnę, organizacyjną, poświęconą przygotowaniu wlaściwych prac Komisji Międzyrządowej .

Ze strony ukraińskiej przewodniczył obradom prof. dr Ołeksandr Fedoruk, Przewodniczący Komisji Narodowej do Spraw Powrotu do Ukrainy Dóbr Kultury przy Gabinecie Ministrów Ukrainy. Uczestniczyła w nich również jego zastępczyni, p. Walentyna Wrublewska, szczególnie zainteresowana sprawami bibliotecznymi.

Uzgodniono składy obu członów komisji: polskiego i ukraińskiego, oraz plan i tok pracy. $\mathrm{Na}$ wniosek strony ukraińskiej zwiększona została liczba uczestników Komisji / po 9 osób + przewodniczący z każdej strony / . Ukraińcy włączyli do Komisji m.in. prof. dr Łarysę Kruszelnicką, Dyrektora Lwowskiej Biblioteki Naukowej im. W. Stefanika. Analogicznie, po stronie polskiej znalazł się dr Adolf Juzwenko, Dyrektor Biblioteki Ossolineum we Wrocławiu. Ustalono też, że pierwsze spotkanie nowopowołanej Komisji Międzyrządowej odbędzie się we Lwowie.

W czasie pobytu w Kijowie członkowie delegacji polskiej zapoznali się ze stanem zachowania księgozbioru Stanisława Augusta Poniatowskiego w Centralnej Bibliotece Naukowej im. V. Vernadskiego, oraz przebiegiem prac nad rejestracją książek, prowadzanych przez polskich bibliotekarzy pod egidę Pracowni Dokumentacji Księgozbiorów Historycznych Biblioteki Narodowej. Rozmawiano m.in. o przyszłości tej kolekcji, ale do konkretnych ustaleń nie doszło. Może w przyszłości zdoła posunąć sprawę naprzód Komisja Międzyrządowa?

Pierwsze posiedzenie Komisji Międzyrządowej, zgodnie z ustaleniami kijowskimi, odbyło się we Lwowie w dn. 13-16 maja 1997 r. Ze strony polskiej środowisko bibliotekarskie reprezentowali tam: dr A. Juzwenko i prof. B. Bieńkowska /prof. A. Manikowski był nieobecny/. Ścisły związek z naszą problematyką ma archiwistyka, reprezentowana w Komisji Międzyrządowej przez dr Andrzeja Biernata, Zastępcę dyrektora w Naczelnej Dyrekcji Archiwów Państwowych.

W wyniku ożywionych, by nie powiedzieć burzliwych, dyskusji przyjęty został Protokól podpisany ostatecznie przez obie strony. Ustalono w nim m.in.:

... 4. Strona polska ocenia z uznaniem wysilki zmierzajace do zapewnienia opieki $i$ konserwacji oraz ogólny stan zasobów dóbr kultury zwiazanych $z$ historiq $i$ kulturq Polski $i$ Ukrainy i stwierdzila konieczność kontynuacji prac konserwatorskich. 
5. Strony wyrazity wspólne życzenie, aby każde przyszłe posiedzenie bylo zwiqzane $z$ wizjq lokalnq archiwów, bibliotek, muzeów zgodnie z interesem każdej ze stron.

6. Strony stwierdzily konieczność wzmożenia wysilków w dziedzinie poszukiwania, rejestracji, wymiany informacji i udostępniania dóbr kultury zwiqzanych z historia i kulturq Polski i Ukrainy, które zostaly uznane za utracone i bezprawnie przemieszczone na terytorium drugiej strony.

7. Dla realizacji powyższych celów postanowiono powolać polsko-ukraińskie zespoty ekspertów do spraw:

a/ archiwaliów historycznych;

b/ zasobów bibliotecznych;

c/ dziel sztuki,

Komisja określi ich status, tryb i porzqdek pracy.

W celu uregulowania spraw bylej Biblioteki „, Ossolineum”, obie strony postanowity utworzyć osobnq polsko-ukraińska grupe ekspertów. Strona ukraińska podniosla problem zabytköw z księgozbioru Kapituty Przemyskiej.

8. Strony uzgodnily, że wnioski rewindykacyjne będą sktadane przez wspótprzewodniczacych Komisji droga dyplomatyczna. ${ }^{3}$

Na zakończenie obrad Komisji Międzyrządowej odbyła się konferencja prasowa, przeznaczona dla dziennikarzy ukraińskich. Na tym forum, niespodziewanie dwóch ukraińskich czlonków Komisji wystapiło z gwałtownym oskarżeniem Polski o rażące nieposzanowanie zabytków kultury ukraińskiej przechowywanych w naszym kraju. Jako przykład posłużyło rzekome poniewieranie fragmentów archiwum Towarzystwa Naukowego im. Szewczenki w Bibliotece Narodowej. Reprezentanci polscy jasno i kompetentnie odparli zarzuty, a wkrótce potem, już z Warszawy przesłane zostały dokumenty całkowicie obalające oskarżenia. Pozostał jednak przykry osad nieufności.

Mimo takich czy innych przeszkód, które wszak są nieuniknione wśród przedstawicieli narodów o tak bardzo skomplikowanej historii i diametralnie odmiennych poglądach na wiele kwestii dotyczących przeszłości, lwowskie spotkanie przyczyniło się do zbliżenia stanowisk w podstawowej kwestii: mianowicie do przekonania, że wzajemna pomoc i współpraca jest moźliwa i pożyteczna. Co więcej, że stanowi jedyną drogę rozwiązywania spraw konfliktowych, które w końcu muszą zostać pozytywnie uregulowane.

Członkowie polskiej delegacji mieli możliwość obejrzenia magazynów m.in. Archiwum Historycznego oraz Lwowskiej Naukowej Biblioteki im. W. Stefanika /w tym także magazynu w kościele pojezuickim/, gdzie, 
jak wiadomo, przechowywane są również zbiory Ossolińskich. W trakcie rzeczowych rozmów z gospodarzami rozważane były projekty współpracy w zakresie dokumentacji, konserwacji i reprografii zbiorów zabytkowych, wymiany dubletów i wspólnych programów naukowych. Planowaliśmy, że konkretyzacją i realizacją tych zamierzeń zajmą się uzgodnione właśnie grupy ekspertów.

Niestety, zaplanowane pierwotnie na czerwiec rozpoczęcie prac przez zespoły ekspertów nie doszło jeszcze do skutku. Dotychczas /grudzień 1997r./ strona ukraińska nie podała nawet propozycji personalnych. Nadal jednak sądzę, a jak wynikało $z$ naszych rozmów we Lwowie, nie jestem odosobniona w tym przekonaniu, że bardzo wiele konkretnych spraw można byłoby uzgodnić i przeprowadzić dzięki porozumieniu fachowców na zasadzie „małych kroków we właściwych kierunkach”.

Oczywiste jest nasze zainteresowanie zbiorami polskimi pozostającymi na Ukrainie, ale również musimy wykazać zrozumienie dla troski naszych sąsiadów o ich dziedzictwo kulturalne znajdujące się w Polsce.

Wypowiedzi ukraińskich członków delegacji , zarówno na sali obrad jak też wcześniej i później, wskazują, że chcieliby oni wyjść poza ramy „ochrony i zwrotu dóbr kultury utraconych i bezprawnie przemieszczonych podczas II wojny światowej" i objać programem współpracy wszystkie polsko-ukraińskie zabytki piśmiennicze, bez względu na sytuację historyczną i prawną zachowanych obiektów. Wskazują na to m.in, zapytania a losy książek z byłej Biblioteki Kapituły Przemyskiej, czy też ukrainików zgromadzonych w Bibliotece Publicznej m. st. Warszawy przed wybuchem II wojny światowej.

Wydaje się, że również nasze dążenia powinny zmierzać w analogicznym kierunku. Wszak dzieje cennych dla nas kolekcji sięgają nieraz znacznie dawniejszych czasów i nie wiążą się $\mathrm{z}$ wydarzeniami wojennymi, Przykładem może slużyć Biblioteka Stanisławowska zachowana w Kijowie.

We Lwowie ustalono, że następne posiedzenie Komisji Międzyrządowej odbędzie się w październiku 1997 r, Tym razem gospodarzem miała być Polska, a jako miejsce obrad nasi ukraińscy kontrahenci wskazywali Przemyśl. Do spotkania w 1997 r. jednak nie doszło. W toku korespondencji okazało się, że delegacja ukraińska nie była doń jeszcze przygotowana. Również z Polski, po zmianach personalnych zaistniałych w wyniku wyborów, nie było impulsów przynaglających.

Ale oczywiście zapoczątkowany dialog istnieje i będzie kontynuowany na rozmaitych szczeblach, Zarówno wypowiedzi oficjalne, jak teksty dwu- 
stronnych umów o współpracy kulturalnej stwarzają możliwości prawdziwie owocnego współdziałania. Z natury rzeczy stanowią one tylko ramy ogólne, które dobrze byłoby wypełnić praktycznymi dzialaniami na polu ochrony i udostępnienia dziedzictwa piśmienniczego. W tej sytuacji bardzo wiele zależy, i w najbliższej przyszłości będzie zależało, od bibliotekarzy pracujących po obu stronach granicy polsko-ukraińskiej.

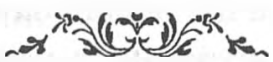

\section{Przypisy:}

${ }^{1}$ Artykuł stanowi skróconą wersję referatu przedstawionego podczas obrad IV Forum PTB n.t. Z problemów ochrony europejskiego i narodowego dziedzictwa piśmienniczego w dn. 2 grudnia 1997 t. w Warszawie.

${ }^{2}$ Tekst niepublikowany, Cytuję według maszynopisu, s. 2. Przechowywany w Biurze Pełnomocnika Rządu...

${ }^{3}$ Tekst niepublikowany, Cytuję wedhug maszynopisu, s. 2-3. Przechowywany w Biurze Pełnomocnika Rządu... 